\title{
The frequency of CIDOS among Mechanical Engineering Students
}

\author{
Ahmady Bin Solong, Ahmad Nasir Bin Mohamed Noor, and Mohamad Sophian Borhan
}

\begin{abstract}
Curriculum information document online System (CIDOS) is an online learning management system that was used by Politeknik Kuching Sarawak. Hence, this research intended to study the frequency of CIDOS usage among Mechanical Engineering Students and the factors that may affect the frequency of usage since the implementation of CIDOS. Other than that, the relationship between internet speed and skilfulness in using CIDOS with frequency of CIDOS usage were studied. Questionnaires were used to collect data from the sample. Total of 600 respondents were chosen to collect data for data analysis through SPSS version 20. This study, mean and Pearson correlation test were conducted to test the data. The result shown that frequency and perception of CIDOS usage was neutral among Mechanical Engineering students. The research also shown that internet speed and also skilfulness in using CIDOS have direct positive effect on frequency of CIDOS usage among students.
\end{abstract}

Keywords — CIDOS Usage, Frequency, Perception, students

\section{INTRODUCTION}

Learning Management System (LMS) is software that eased the management system of learning and teaching process. As the Learning Management Systems manage the log-in of registered users, manage course catalogues, record data from learners, and provide reports to management (Hall B, 2001). Yet this online learning services to help students, lecturer and also administrator in a systematic way (Greenberg, 2002). LMS allows the institution to organize and manage all aspect of education in an efficient and better manner (Keegan, 2000). LMS is operating with backbone of web for planning, presenting and conveying the content of syllabus, leading student involvement and also to access student achievement (Hall, 2001). Lecturers were able to easily manage teaching and learning process through LMS as students were allowed to obtain learning materials without the constraint factors of time and place.

\section{Problem Statement}

i. What is the frequency of the usage of CIDOS among students from Mechanical Engineering courses?

Ahmady Bin Solong, Ahmad Nasir Bin Mohamed Noor, and Mohamad Sophian Borhan are with Politeknik Kuching Sarawak, Sarawak, Malaysia ahmadysolong@gmail.com, nasir@poliku.edu.my, msophian@ poliku.edu.my ii. What is the perception of students from Mechanical Engineering courses toward the usage CIDOS?

iii.Is the frequency of usage of CIDOS affected by the skillfulness in using CIDOS among Mechanical Engineering students?

iv. Is the frequency of usage of CIDOS affected by the stability of internet among Mechanical Engineering students?

\section{Research Objectives}

The following are the objectives in this research:

i. To determine the frequency of usage of CIDOS among Mechanical Engineering students.

ii. To determine the perception of engineering students toward the usage of CIDOS.

iii. To determine the effect of the skillfulness in using CIDOS on the frequency of the usage of CIDOS among Mechanical Engineering students.

iv. To determine the effect of internet speed on the frequency of CIDOS usage among engineering students.

\section{Scope of Research}

The research scope focused on the frequency and also perception of CIDOS usage among Mechanical Engineering students from Politeknik Kuching Sarawak. While also focus to testing of the skillfulness of using CIDOS and internet speed in affecting the CIDOS usage frequency.

\section{Research Contribution}

i. Give an insight to institution to increase the usage of CIDOS portal among Mechanical Engineering students.

ii. Provides information and suggestion to the institution to improve the aspects which encourage Mechanical Engineering students to use CIDOS.

iii. Provides an insight for ICT staffs regarding the importance of mastering the skill to use CIDOS and internet speed.

\section{Research Hypotheses}

Hypotheses were used for research question 3 and 4.

Null Hypothesis (H01)

There is no relationship between internet speed and the frequency of CIDOS usage among Mechanical Engineering students.

Alternative Hypothesis (Hal)

There is a relationship between internet speed and the frequency of CIDOS usage among Mechanical Engineering students.

Null Hypothesis (HO2) 
There is no relationship between skilfulness of using CIDOS and frequency of CIDOS usage among Mechanical Engineering students.

Alternative Hypothesis (Ha2)

There is a relationship between skillfulness of using CIDOS and frequency of CIDOS usage among Mechanical Engineering students.

\section{METHODOLOGY}

Questionnaires were used in this research to collect data for analysis. Total of 600 questionnaires were collected from 600 respondents. SPSS version 20 software was used to analyze the collected data. The methodologies used in this research were descriptive analysis and Pearson Correlation Analysis.

\section{Data Interpretation Guideline}

\section{A. Mean}

Mean was used to interpret the degree or intensity of certain variables in average or overall as shown in Table 1.

Table 1: Range of mean scores and intensity

\begin{tabular}{|c|c|c|c|c|}
\hline $\begin{array}{l}\text { Mean } \\
\text { Score }\end{array}$ & $\begin{array}{c}\text { Frequency } \\
\text { of CIDOS } \\
\text { Usage }\end{array}$ & $\begin{array}{l}\text { Perception to } \\
\text { CIDOS }\end{array}$ & $\begin{array}{l}\text { Skilfulness in } \\
\text { Using CIDOS }\end{array}$ & $\begin{array}{l}\text { Internet } \\
\text { Speed }\end{array}$ \\
\hline $1.00-1.99$ & Very Low & Very Bad & Very Bad & Very Slow \\
\hline $2.00-2.99$ & Low & $\mathrm{Bad}$ & $\mathrm{Bad}$ & Slow \\
\hline $3.00-3.99$ & Neutral & Neutral & Neutral & Neutral \\
\hline $4.00-4.99$ & High & Good & Good & Fast \\
\hline 5.00 & Very High & Very Good & Very Good & Very Fast \\
\hline
\end{tabular}

\section{B. Pearson Correlation}

Pearson Correlation has its own intensity as shown in the Table 2 to access the intensity, $\mathrm{R}$ value will be referred. Other than that, $\mathrm{P}$ value was accessed to determine the significance of the relationship. If $\mathrm{P}<0.05$, the relationship was significant and vice versa (Mohd Najib, 2003).

Table 2: Pearson Correlation

\begin{tabular}{|c|c|}
\hline Pearson Correlation Value & Score \\
\hline 0.70 or more & Very Strong \\
\hline 0.50 to 0.69 & Strong \\
\hline 0.30 to 0.49 & Normal \\
\hline 0.10 to 0.29 & Weak \\
\hline 0.01 to 0.09 & Very Weak \\
\hline
\end{tabular}

\section{RESULTS AND DISCUSSION}

The analysis are divided into four sections, there are respondent's demography, Descriptive Analysis, Relationship between Skillfulness in using CIDOS and the Frequency of CIDOS Usage among Mechanical Engineering Students and Relationship between internet speed and frequency of CIDOS usage among Mechanical Engineering Students. In the respondent's demography include gender, semester of studying and academic qualification.

\section{A. Demographic Analysis}

Gender

Table 3: Gender

\begin{tabular}{|l|c|c|}
\hline \multicolumn{1}{|c|}{ Gender } & & \\
\hline & Frequency & Percent \\
\hline Male & 418 & 69.7 \\
\hline Female & 182 & 30.3 \\
\hline Total & 600 & 100.0 \\
\hline
\end{tabular}

According to the Table 3, there are more male students than female students in Mechanical Engineering as there are $69.7 \%$ male and $30.3 \%$ female. As noticing that females are less interested with Mechanical Engineering studies.

Semester

Table 4: Semester

\begin{tabular}{|l|c|c|}
\hline \multicolumn{1}{|c|}{ Semester } & & \\
\hline & Frequency & Percent \\
\hline First & 52 & 8.7 \\
\hline Second & 154 & 25.7 \\
\hline Third & 160 & 26.7 \\
\hline Fourth & 133 & 22.2 \\
\hline Fifth & 101 & 16.8 \\
\hline Total & 600 & 100 \\
\hline
\end{tabular}

According to the Table 4, out of 600 respondents, $8.7 \%$ was having their first semester, $25.7 \%$ having second semester, $26.7 \%$ having third semester, $22.2 \%$ fourth semester and $16.8 \%$ fifth semester.

\section{Academic Qualification}

Table 5: Academic Qualification

\begin{tabular}{|l|c|c|}
\hline \multicolumn{1}{|c|}{ Academic Qualification } & & \\
\hline & Frequency & Percent \\
\hline SPM & 455 & 75.8 \\
\hline STPM & 55 & 9.2 \\
\hline Certification & 90 & 15.0 \\
\hline Total & 600 & 100.0 \\
\hline
\end{tabular}

In the academic qualification section, Table 5, majority of the students were SPM graduates $(75.8 \%)$. On the other hand, $9.2 \%$ were STPM graduates and $15 \%$ were Certification holder 


\section{B. Descriptive Analysis}

Table 6: Descriptive Statistics

\begin{tabular}{|l|c|c|c|c|c|}
\hline & $\mathrm{N}$ & Minimum & Maximum & Mean & $\begin{array}{c}\text { Std. } \\
\text { Deviation }\end{array}$ \\
\hline Usage_CIDOS & 600 & 1.00 & 5.00 & 3.0195 & 1.01598 \\
\hline Perception_CIDOS & 600 & 1.00 & 5.00 & 3.0960 & 1.00438 \\
\hline Valid N (listwise) & 600 & & & & \\
\hline
\end{tabular}

As according to the Table 6, the mean value for frequency of CIDOS usage and perception of students on CIDOS were 3.0195 and 3.0960 respectively. Both of the mean value falls in the range of neutral which is 3.00-3.99. The frequency of CIDOS usage was neutral among Mechanical Engineering students, while student's perception toward CIDOS was neutral as well.

C. Relationship between Skillfulness in using CIDOS and the Frequency of CIDOS Usage among Mechanical Engineering Students

Table 7: Correlations

\begin{tabular}{|c|c|c|c|}
\hline & & Skilfulness_CIDOS & Usage_CIDOS \\
\hline \multirow[t]{3}{*}{ Skilfulness_CIDOS } & $\begin{array}{l}\text { Pearson } \\
\text { Correlation }\end{array}$ & 1 & $.624^{* *}$ \\
\hline & Sig. (2-tailed) & & .000 \\
\hline & $\mathrm{N}$ & 600 & 600 \\
\hline \multirow[t]{3}{*}{ Usage_CIDOS } & $\begin{array}{l}\text { Pearson } \\
\text { Correlation }\end{array}$ & $.624^{* *}$ & 1 \\
\hline & Sig. (2-tailed) & .000 & \\
\hline & $\mathrm{N}$ & 600 & 600 \\
\hline
\end{tabular}

**. Correlation is significant at the 0.01 level (2-tailed).

According to the Table 7, the P value was 0.000 , which is less than 0.05 . This indicated the relationship was significant. Then, the strength of relationship was accessed. The $\mathrm{R}$ value was 0.624 , which implied the relationship was strong and positive.

Therefore, the alternate hypothesis was accepted (Ha2) as there is a relationship between skilfulness in using CIDOS and frequency of CIDOS usage among Mechanical Engineering Students.

\section{Relationship between internet speed and frequency of CIDOS usage among Mechanical Engineering Students.}

Table 8: Correlations

\begin{tabular}{|l|l|c|c|}
\hline & & Internet Speed & Usage_CIDOS \\
\hline Internet Speed & Pearson Correlation & 1 & $.608^{* *}$ \\
\hline & Sig. (2-tailed) & & .000 \\
\hline & $\mathrm{N}$ & 600 & 600 \\
\hline Usage_CIDOS & Pearson Correlation & $.608^{* *}$ & 1 \\
\hline & Sig. (2-tailed) & .000 & \\
\hline & $\mathrm{N}$ & 600 & 600 \\
\hline
\end{tabular}

**. Correlation is significant at the 0.01 level (2-tailed).

The Table 8 shows there is a strong positive relationship between internet speed and frequency of CIDOS usage. From the Table 8 , the $\mathrm{P}$ value was 0.000 , which is less than 0.05 . This indicates the relationship was significant. Then, the strength of relationship was accessed where the $R$ value was 0.608 . The alternate hypothesis was accepted (Ha1).

\section{CONCLUSION AND SUGGESTION}

The frequency of CIDOS usage was neutral so as the perception of CIDOS among Mechanical Engineering Students. It shows that half of the students are not from well off family which able to allows them to have devices and internet services which enables them to get into the CIDOS system. While most of the students are not that keen to explore the CIDOS system as they found it is rather complex. Yet they are double discouraged with the internet speed and coverage which always has been hindrance to the approach of the CIDOS systems. As Polytechnic Kuching Sarawak is located to a rural area, the service of data approach and strength are very limited. Yet the provided students WIFI system is limited to a certain area only.

Hence the related parties should take the steps to improve to counter the situation that had been highlighted from the research. As the CIDOS system is a good platform to enhance the learning process of the students while in the institution.

\section{REFERENCES}

[1] Greenberg, L. (2002). LMS and LCMS: What's the Difference? Learning Circuits from http://www.learningcircuits.org/2002/dec2002/greenberg.htm

[2] Hall, B. 2001. New Technology Definitions. www.brandonhall.com/public/glossary/index.htm

[3] Keegan, D. 2000. Seamless interfaces: from distance education to web based training. Istruzione a distanza, 16, Aprile 2000, pp. 7-21. http://www.nki.no/eeileo/research/seamless.htm

[4] Mohamad Najib Abdul Ghafar (1999), Penyelidikan Pendidikan, Skudai Universiti Teknology Malaysia.

[5] Mohamad Najib Abdul Ghafar (2003), Rekabentuk tinjauan Soal Selidik Pendidikan, Skudai Universiti Teknology Malaysia. 